KANSAS JOURNAL of MEDICINE

\section{Clinical Characteristics of Necrotizing Soft Tissue Infection and Early Toxic Shock-Like Syndrome Caused by Group G Streptococcus: Case Report and Review of Literature}

\author{
Khalil Choucair, M.D., M.Sc. ${ }^{1}$ Katia El Jurdi, M.D., M.Sc. ${ }^{1}$, \\ K. James Kallail, Ph.D. ${ }^{1}$, Thomas A. Moore, M.D.,2 \\ 'University of Kansas School of Medicine-Wichita, Wichita, KS \\ Department of Internal Medicine \\ ${ }^{2}$ Infectious Disease Consultants, Wichita, KS \\ Received Jan. 2, 2021; Accepted for publication March 10, 2021; Published online June 21, 2021 \\ https: doi.org 10.17161 kim.voll415038
}

\section{INTRODUCTION}

Necrotizing soft tissue infections (NSTIs) are uncommon, but rapidly spreading infections, that involve the fascia and subcutaneous tissue. ${ }^{1}$ NSTIs can be complicated by toxic shock syndrome (TSS), which usually are caused by $\beta$-hemolytic streptococci, mostly attributed to group A Streptococcus (GAS). ${ }^{2,3}$ In fact, the original definition of streptococcal TSS in 1993 required the isolation of GAS, along with parameters indicative of multi-organ dysfunction. ${ }^{4}$ TSS remains associated with high mortality rates exceeding 40 - 50\%, despite adequate antimicrobial treatment. ${ }^{5-7}$ However, group $\mathrm{G} \beta$-hemolytic streptococci (GGS), historically identified as part of the normal flora of the pharynx, gastrointestinal tract and skin, are an uncommon cause of NSTI-TSS. ${ }^{8}$ We report the case of a male with NSTI of the penile shaft, and toxic shock-like syndrome (TSLS) attributable to GGS. Only 16 similar cases have been reported.

\section{CASE REPORT}

A 32-year-old previously healthy male presented with penile pain following a 36-hour entrapment of the penile shaft by a plastic ring. He received amoxicillin-clavulanate with urgent surgical ring removal and exploratory flexible cystoscopy. On postoperative day one, he developed fever, chills, and excruciating pain with guarding across the pelvic area. The penile shaft was disproportionately swollen distally, cold to touch, necrotic, and devoid of sensation, with formation of new tense blisters. A new, erythematous skin rash overlying the pubic symphysis and both inguinal canals was observed, with well-demarcated, flat borders (Figure 1). Bilateral inguinal lymphadenopathy was present; identification of crepitus was limited by tenderness.

Labs were remarkable for mild lactic acidosis $(2.1 \mathrm{mmol} / \mathrm{L})$, hyperazotemia $(25 \mathrm{mmol} / \mathrm{L})$, hyponatremia $(126 \mathrm{mEq} / \mathrm{L})$, and thrombocytopenia $\left(107 \times 10^{3} / \mathrm{uL}\right)$. Interval examination revealed worsening symptoms and rash progression, raising suspicion for NSTI superimposed by early stage streptococcal-induced TSLS. Peripheral blood, fluid from bullae, and penile skin swabs were cultured. IV immunoglobulin (IVIG) was administered and antibiotic therapy was modified to IV piperacillin-tazobactam and clindamycin.

On postoperative day two, he became afebrile and rash progression halted. He underwent penile/scrotum fasciotomy and debridement.
Blood cultures remained negative, but fluid from the bullae, the penile skin, and surgical tissue specimen grew GGS. On postoperative day three, the rash receded. Antibiotic therapy was discontinued on day six, and he received a skin graft on day seven.

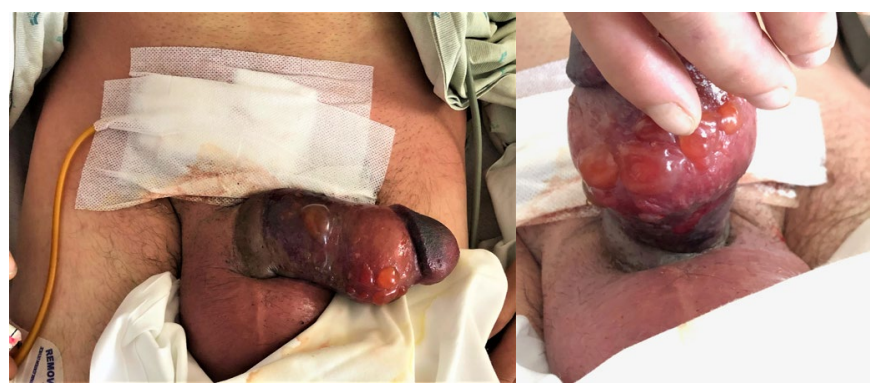

Figure 1. View of the G $\beta$-hemolytic Streptococci necrotizing soft tissue infection involving the penile area with necrosis of distant shaft, prior to therapy and surgical debridement. (Left) A new, erythematous skin rash overlying the pubic symphysis and both inguinal canals was observed, with well-demarcated, flat borders. (Right) Figure illustrates disproportionate swelling and necrosis distally, with formation of new tense blisters.

\section{DISCUSSION}

A review of the English literature revealed 16 additional cases of NSTI caused by GGS. ${ }^{9-17}$ Clinical characteristics and outcomes are summarized in Table 1. The mean age of the total of 16 cases was 62.9 years (range: 46 - 80 yrs.). The majority were males $(n=9 ; 56.2 \%)$ and had other co-morbidities $(\mathrm{n}=10 ; 62.5 \%)$, including liver cirrhosis $(\mathrm{n}=$ $1)$, malignancy $(n=1)$, multiple sclerosis $(n=1)$, syringomyelia $(n=1),{ }^{18}$ arthritis $(\mathrm{n}=\mathrm{l})$, and diabetes mellitus which was the most common comorbidity $(\mathrm{n}=5 ; 50 \%)$.

The mean duration of symptoms prior to presentation was 3.2 days ( \pm 2.2 days) and ranged from one to seven days. Common presenting manifestations were swelling with redness $(n=16 ; 100 \%)$, severe acute pain $(n=8 ; 50 \%)$, and blister formation $(n=7 ; 43.75 \%)$. The lower extremities (leg, ankle, and foot) were the most commonly involved sites ( $\mathrm{n}=12 ; 75 \%)$, with one case involving the arm, ${ }^{12}$ two cases involving the knees, ${ }^{10}$ and one case involving multiple sites simultaneously.$^{13}$ Progression to TSS or TSLS occurred in nine cases (56.3\%). The diagnosis was established by isolating GGS from the site of involvement in all cases $(n=16 ; 100 \%)$ : tissue $(n=12)$, bullae/blisters $(n=2)$, and joint fluid $(n=2)$. Bacteremia occurred in $25 \%$ of patients $(n=4){ }^{11-13}$ Treatment included penicillin-based antibiotic regimen in all patients and varying degrees of surgical debridement $(n=15 ; 93.75 \%)$. Four patients received IVIG therapy. The overall mortality rate was $25 \%(n=4)$, with equal rates in those who received IVIG $(n=1 / 4)$ and those who did not $(\mathrm{n}=3 / 12)$; all patients who died developed TSLS.

Our patient presented with less than two days history of penile shaft entrapment with no clear sign of infection. He was treated solely based on clinical presentation which was highly suggestive of streptococcal TSS. Implication of GGS as the organism responsible for this illness and clinical progression was only later established based on an isolated specimen from surgical tissue and blister fluid which showed Grampositive cocci and GGS growth on culture. The case thus highlighted the importance of early TSLS signs recognition, and the ensuing prompt management based on pure clinical presentation. 
Table 1. Characteristics of Group G Streptococcus necrotising fasciitis.

\begin{tabular}{|c|c|c|c|c|c|c|c|}
\hline $\begin{array}{c}\text { Age } \\
\text { (years)/sex }\end{array}$ & Co-morbidities & Site & Source of culture & $\begin{array}{c}\text { TSS/TSLS? } \\
(\mathbf{Y} / \mathbf{N})\end{array}$ & Therapy & Outcome & Reference \\
\hline $75 / F$ & Syringomyelia & Left leg & Tissue & $\mathrm{N}$ & Antibiotics, debridement & Survived & [36] \\
\hline $80 / F$ & None & Right leg & Tissue & $\mathrm{N}$ & Antibiotics, debridement & $\begin{array}{l}\text { Survived (skin } \\
\text { graft) }\end{array}$ & [9] \\
\hline $49 / F$ & None & Left ankle & Tissue & $\mathrm{N}$ & Antibiotics, debridement & Survived & [9] \\
\hline $75 / \mathrm{M}$ & None & Right leg & Tissue & $\mathrm{N}$ & Antibiotics, debridement & Survived & [9] \\
\hline $71 / M$ & None & Left foot & Skin/bulla & $\mathrm{N}$ & Antibiotics, debridement & $\begin{array}{l}\text { Survived (skin } \\
\text { graft) }\end{array}$ & [14] \\
\hline $59 / \mathrm{M}$ & Unknown & Right leg & Skin/blister & $\mathrm{Y}$ & Antibiotics, debridement & Died & [15] \\
\hline $64 / F$ & $\mathrm{DM}$ & Both legs & Tissue & $\mathrm{Y}$ & Antibiotics & Died & [17] \\
\hline $65 / F$ & $\mathrm{RA}$ & Right arm & Blood/tissue & $\mathrm{Y}$ & Antibiotics, amputation & Died & [12] \\
\hline $52 / \mathrm{M}$ & $\mathrm{DM}$ & Right leg & Tissue & $\mathrm{Y}$ & Antibiotics. debridement & Survived & [16] \\
\hline $52 / \mathrm{M}$ & $\mathrm{DM}$ & Right leg & Tissue & $\mathrm{N}$ & Antibiotics, debridement & Survived & [13] \\
\hline $59 / \mathbf{M}$ & $\mathrm{HCL} / \mathrm{FN}$ & Left leg & Blood/tissue & $\mathrm{N}$ & Antibiotics, debridement & Survived & {$[13]$} \\
\hline $58 / \mathbf{M}$ & Liver cirrhosis & $\begin{array}{l}\text { Left knee, } \\
\text { forearm, wrist, } \\
\text { digits }\end{array}$ & Blood/tissue & Y & $\begin{array}{l}\text { Antibiotics, IVIG, } \\
\text { debridement }\end{array}$ & Died & {$[13]$} \\
\hline $73 / \mathrm{F}$ & $\begin{array}{l}\text { Morbid obesity, } \\
\text { HTN, DM, PVD }\end{array}$ & Left leg/ankle & Blood/tissue & Y & Antibiotics, debridement & Survived & [11] \\
\hline $46 / F$ & MS, LLL & Right leg & Tissue & $\mathrm{Y}$ & $\begin{array}{c}\text { Antibiotics, IVIG, } \\
\text { debridement }\end{array}$ & Survived & {$[10]$} \\
\hline $63 / \mathrm{M}$ & None & $\begin{array}{l}\text { Both knee } \\
\text { joints }\end{array}$ & Joint fluid & Y & $\begin{array}{l}\text { Antibiotics, IVIG, } \\
\text { arthroscopic washes }\end{array}$ & Survived & {$[10]$} \\
\hline $66 / M$ & DM, TKR & Prosthetic knee & $\begin{array}{l}\text { Prosthetic knee/ } \\
\text { fluid }\end{array}$ & $\mathrm{Y}$ & $\begin{array}{c}\text { Antibiotics, IVIG, } \\
\text { debridement }\end{array}$ & Survived & {$[10]$} \\
\hline $32 / \mathrm{M}$ & None & Penis & Bulla/tissue & $\mathrm{Y}$ & $\begin{array}{c}\text { Antibiotics, IVIG, } \\
\text { debridement }\end{array}$ & Survived & $\begin{array}{l}\text { Present } \\
\text { work }\end{array}$ \\
\hline
\end{tabular}

M = Male; F- Female; Y: Yes; N: No; DM: Diabetes Mellitus; RA: Rheumatoid Arthritis; HCL: Hairy Cell Leukemia; FN: Febrile Neutropenia; HTN: Hypertension; PVD: Peripheral Vascular Disease; MS: Multiple Sclerosis; LLL: Lower limb lymphedema; TKR: Total Knee Replacement

While originally identified and described by Lancefield and Hare as part of the normal flora, previous case reports have indicated that GGS also could cause complicated infections, such as cellulitis, osteomyelitis, septic arthritis, meningitis, endocarditis, and bacteremia. ${ }^{19-22}$ Invasive disease due to GGS has been reported mostly in patients with underlying debilitating conditions including malignancy, rheumatoid arthritis, diabetes mellitus, injection drug use, and HIV infection, as well as in more elderly patients (Table 1 ). ${ }^{10,11,13,16-18}$

Our patient was young and healthy with no known history of comorbid conditions. Whether the penile shaft entrapment and the ensuing low blood flow and necrosis could mimic the low terminal vascular supply and/or local impairment in defense mechanism observed in diabetes mellitus patients remains a plausible hypothesis, particularly in light of the observation that most cases had lower extremity involvement and diabetes mellitus (Table 1). Our review of literature did not always suggest an apparent precipitating cause of GGS-NSTI and TSS.

The presented case was unique in respect to two aspects. The first one pertains to the rarity of the underlying causative organism (only 16 reported cases in the English literature); as mentioned earlier GGS historically has been characterized as part of the normal flora with rare cases describing its involvement in pathologic states. Our case was one of these rare occurrences. Second, within the different reported cases, invasive GGS invariably has been linked to existing underlying comorbidities. In contrast, our case was unique in that it reflected the occurrence of this potentially lethal infection in an otherwise young and healthy individual, hence highlighting the importance of a low clinical suspicion threshold for GGS-NSTI.

Over the past years, the number of reported GGS-NSTI cases, with or without TSS, has been on the rise. In fact, this observation prompted Wong et al. ${ }^{18}$ to conduct a retrospective chart review of patients admitted to Long Island College Hospital in Brooklyn, New York, between January 2003 and December 2007. Only adult patients with microbiologically documented GGS infection were included in the study. A total of 73 patients with GGS infections were admitted to the hospital during the five-year study period, with the number increasing yearly and in an incremental fashion from three cases in 2003 to 28 in 2007. This study, along with the different cases reported (Table 1), reflects a clear increase in trend, and raises the possibility of GGS being an emerging human pathogen. The reasons of this increase remain 
KANSAS JOURNAL of MEDICINE GROUP G STREPTOCOCCUS AND NECROTIZING SOFT TISSUE INFECTION

continued.

unknown and could relate to increase in potential risk factors, such as increased prevalence of diabetes mellitus or cancer, or to improved detection methods. Furthermore, emergence of resistance patterns in response to increased antibiotics use worldwide may explain possible changes/increases in GGS virulence. Hashikawa et al. ${ }^{23}$ microbiologically characterized 12 strains of group $C$ and $G$ streptococci that caused TSS. Despite GGS TSS manifesting clinically in a similar fashion to GAS, only the spegg gene, which encodes a super-antigen found in GAS stains, was detected in S. dysgalactiae (GGS strain), but no other apparent virulence factor responsible for the TSS pathogenesis was identified. Further multi-center studies are warranted to characterize the increasing trend of GGS and define underlying host risk factors, and strain virulence factors.

As mentioned, NSTI and TSS treatment in our patient was initiated solely based on clinical presentation and high index of suspicion with no imaging to characterize the depth of tissue involvement. ${ }^{24}$ Prompt initiation of therapy took precedence over establishing a clear diagnosis, based on both high clinical suspicion and the significantly high morbidity/mortality associated with delayed initiation of therapy. The actual diagnosis was validated clinically later when the patient positively responded to therapy and shock progression halted.

The Laboratory Risk Indicator for Necrotizing Fasciitis (LRINEC) is a score used in the setting of early infection to define the likelihood of NSTI; it is based on indicators including white blood cell count (WBC), hemoglobin (Hgb), sodium (Na), glucose, creatinine ( $\mathrm{Cr}$.), and C-reactive protein (CRP) ${ }^{25,26} \mathrm{~A}$ score greater than six is suggestive of NSTI while less than six is indicative of low risk (but does not exclude risk), suggesting IV antibiotics and serial laboratory monitoring without the need for surgical debridement.

We did not calculate a LRINEC score for our patient. In hindsight, and with the available laboratory values (CRP not obtained), the calculated LRINEC would have been five $\left(\mathrm{WBC}=10.3 \times 10^{3} / \mathrm{uL}\right.$; $\mathrm{Cr}$. $=$ 1.8; Na: $126 \mathrm{mEq} / \mathrm{L}$; and $\mathrm{Hgb}=12 \mathrm{~d} / \mathrm{dL}$ ), suggestive of low risk. This discrepancy between the low LRINEC score and the actual clinical picture reveals yet again the importance of clinical history and physical exam in clinical decision making. High suspicion for NSTI on clinical ground warrants a straight operative debridement approach, regardless of LRINEC score.

A recent assessment of the LRINEC score has recommended its cautious use given a poor performance in external validation. ${ }^{27}$ In this study which involved patients with established diagnoses of cellulitis ( $\mathrm{n}=948)$ and necrotizing fasciitis $(\mathrm{n}=135)$, a retrospective computation of the LRINEC score revealed poor predictive value of the score for differentiating between both diseases with a $10.7 \%$ false diagnoses of moderate-to-high risk of necrotizing fasciitis in patients with a confirmed diagnosis of cellulitis. Similarly, and within the group of patients with confirmed necrotizing fasciitis, $63.8 \%$ were categorized as low risk for necrotizing fasciitis using the LRINC score.

Similar to all NSTI, broad spectrum antibiotics and surgical debridement are necessary for a good outcome. Our patient received piperacillin-tazobactam as a regimen, along with both clindamycin and IVIG. Beyond its antibacterial effects, clindamycin is added for its ability to suppress bacterial toxin production. ${ }^{28}$ In fact, use of clindamycin in patients with invasive GAS infection was associated with lower 30-day mortality (15\% vs. 39\% in those who did not receive clindamycin) ${ }^{29}$ Linezolid or tedizolid alternatively can be used in patients with known resistance to clindamycin. ${ }^{1}$ The use of IVIG in patients with streptococcal TSS often has been a subject of debate. The proposed rationale for use of IVIG is to boost antibody levels (passive immunity) in the setting of the overwhelming infection seen in TSS. Several mechanisms have been proposed, including bacterial opsonisation, toxin neutralization, inhibition of $\mathrm{T}$ cell proliferation, and inhibition of inflammatory cytokines. ${ }^{30,31}$ Clinically, IVIG super-antigen neutralizing activity reduced mortality rates in streptococcal TSS. ${ }^{32-34}$ A recent meta-analysis including five studies of patients with streptococcal TSS treated with clindamycin revealed an association between IVIG use and 30-day reduction in mortality (33.7 vs. $15.7 \%)^{35}$

In summary, this work illustrated how NSTI due to GGS can progress, similar to GAS-induced fasciitis, to TSS/TSLS and can be life-threatening. Clinicians should keep a high index of suspicion, especially in patients with underlying co-morbid conditions, and understand the crucial role of early IVIG therapy, the choice of antibiotics with antitoxin properties, and the increasing trend of GGS infections.

\section{REFERENCES}

${ }^{1}$ Stevens DL, Bryant AE. Necrotizing soft-tissue infections. N Engl J Med 2017; 377(23):2253-2265. PMID: 29211672.

2 Rowlands J, Dufort EM, Blog DS, Zansky SM. Underreporting of necrotizing fasciitis and streptococcal toxic shock syndrome in invasive group A streptococcus cases in New York State, 2007-2016. Open Forum Infect Dis 2017; 4(suppl 1):S240-S240.

Ikebe T, Tominaga K, Shima T, et al. Increased prevalence of group A streptococcus isolates in streptococcal toxic shock syndrome cases in Japan from 2010 to 2012. Epidemiol Infect 2015; 143(4):864-872. PMID: 25703404.

${ }^{4}$ Breiman RF, Davis JP, Facklam RR, et al. Defining the group A streptococcal toxic shock syndrome: Rationale and consensus definition. JAMA 1993; 269(3):390-39l. PMID: 8418347.

${ }^{5}$ Davies HD, McGeer A, Schwartz B, et al. Invasive group A streptococcal infections in Ontario, Canada. N Engl J Med 1996; 335(8):547-554. PMID: 8684408

${ }^{6}$ McCormick JK, Yarwood JM, Schlievert PM. Toxic shock syndrome and bacterial superantigens: An update. Annu Rev Microbiol 2001; 55(1):77-104. PMID: 11544350.

${ }^{7}$ O'Loughlin RE, Roberson A, Cieslak PR, et al. The epidemiology of invasive group A streptococcal infection and potential vaccine implications: United States, 2000-2004. Clin Infect Dis 2007; 45(7):853-862. PMID: 17806049.

8 Vartian C, Lerner PI, Shlaes DM, Gopalakrishna KV. Infections due to Lancefield group G streptococci. Medicine 1985; 64(2):75-88. PMID: 3974442.

9 Barker F, Leppard BJ, Seal DV. Streptococcal necrotising fasciitis: Comparison between histological and clinical features. J Clin Pathol 1987; 40(3):335-341. PMID: 3558868.

${ }_{10}$ Baxter M, Morgan M. Streptococcal toxic shock syndrome caused by group G streptococcus, United Kingdom. Emerg Infect Dis 2017; 23(1):127129. PMID: 27983491.

${ }^{11}$ Gupta S, Mansuri N, Kowdley G. Group G streptococcus leading to necrotizing soft tissue infection after left lower extremity radiofrequency venous ablation. J Vasc Surg Cases Innov Tech 2019; 5(2):110-112. PMID: 31193488.

${ }^{12}$ Hirose Y, Yagi K, Honda H, Shibuya H, Okazaki E. Toxic shock-like syndrome caused by non-group A beta-hemolytic streptococci. Arch Intern Med 1997; 157(16):1891-1894. PMID: 9290550. 
13 Humar D, Datta V, Bast DJ, Beall B, De Azavedo JCS, Nizet V. Streptoly$\sin \mathrm{S}$ and necrotising infections produced by group $\mathrm{G}$ streptococcus. Lancet 2002; 359(9301):124-129. PMID: 11809255.

14 Jarrett P, Rademaker M, Duffill M. The clinical spectrum of necrotising fasciitis. A review of 15 cases. Aust N Z J Med 1997; 27(1):29-34. PMID: 9079250.

${ }^{15}$ Kugi M, Tojo H, Haraga I, Takata T, Handa K, Tanaka K. Toxic shock-like syndrome caused by group G Streptococcus. J Infect 1998; 37(3):308-309. PMID: 9892544.

${ }^{16}$ Sharma M, Khatib R, Fakih M. Clinical characteristics of necrotizing fasciitis caused by group G Streptococcus: Case report and review of the literature. Scand J Infect Dis 2002; 34(6):468-471. PMID: 12160177.

${ }_{17}$ Wagner JG, Schlievert PM, Assimacopoulos AP, Stoehr JA, Carson PJ, Komadina K. Acute group G streptococcal myositis associated with streptococcal toxic shock syndrome: Case report and review. Clin Infect Dis 1996; 23(5):1159-1161. PMID: 8922817.

${ }^{18}$ Wong SS, Lin YS, Mathew L, Rajagopal L, Sepkowitz D. Increase in group G streptococcal infections in a community hospital, New York, USA. Emerg Infect Dis 2009; 15(6):991. PMID: 19523319.

19 Liao CH, Liu LC, Huang YT, Teng LJ, Hsueh PR. Bacteremia caused by group G streptococci, Taiwan. Emerg Infect Dis 2008; 14(5):837. PMID: 18439377.

${ }^{20}$ Venezio FR, Gullberg RM, Westenfelder GO, Phair JP, Cook FV. Group G streptococcal endocarditis and bacteremia. Am J Med 1986; 81(1):29-34. PMID: 3728552.

${ }^{21}$ Mohan P, Shanmugam J, Nair A, Tharakan J. Fatal outcome of group-G streptococcal meningitis (a case report). J Postgrad Med 1989; 35(1):49. PMID: 2585338.

22 Burkert T, Watanakunakorn C. Group G streptococcus septic arthritis and osteomyelitis: Report and literature review. J Rheumatol 1991; 18(6):904907. PMID: 1895274.

${ }^{23}$ Hashikawa S, Iinuma Y, Furushita M, et al. Characterization of group C and $\mathrm{G}$ streptococcal strains that cause streptococcal toxic shock syndrome. J Clin Microbiol 2004; 42(1):186-192. PMID: 14715751.

${ }^{24}$ Turecki MB, Taljanovic MS, Stubbs AY, et al. Imaging of musculoskeletal soft tissue infections. Skeletal Radiol 2010; 39(10):957-971. PMID: 19714328.

25 El-Menyar A, Asim M, Mudali IN, et al. The laboratory risk indicator for necrotizing fasciitis (LRINEC) scoring: The diagnostic and potential prognostic role. Scand J Trauma Resusc Emerg Med 2017; 25(1):28. PMID: 28270166.

${ }^{26}$ Wong CH, Khin LW, Heng KS, Tan KC, Low CO. The LRINEC (Laboratory Risk Indicator for Necrotizing Fasciitis) score: A tool for distinguishing necrotizing fasciitis from other soft tissue infections. Crit Care Med 2004; 32(7):1535-1541. PMID: 15241098.

${ }_{27}$ Neeki MM, Dong F, Au C, et al. Evaluating the laboratory risk indicator to differentiate cellulitis from necrotizing fasciitis in the emergency department. West J Emerg Med 2017; 18(4):684-689. PMID: 28611889.

${ }^{28}$ Stevens DL, Maier KA, Mitten JE. Effect of antibiotics on toxin production and viability of Clostridium perfringens. Antimicrob Agents Chemother 1987; 31(2):213-218. PMID: 2882731.

${ }^{29}$ Carapetis JR, Jacoby P, Carville K, Ang SJ, Curtis N, Andrews R. Effectiveness of clindamycin and intravenous immunoglobulin, and risk of disease in contacts, in invasive group a streptococcal infections. Clin Infect Dis 2014; 59(3):358-365. PMID: 24785239.

30 Norrby-Teglund A, Kaul R, Low DE, et al. Plasma from patients with severe invasive group A streptococcal infections treated with normal polyspecific IgG inhibits streptococcal superantigen-induced T cell proliferation and cytokine production. J Immunol 1996; 156(8):3057-3064. PMID: 8609429.

${ }^{31}$ Norrby-Teglund A, Kaul R, Low DE, et al. Evidence for the presence of streptococcal-superantigen-neutralizing antibodies in normal polyspecific immunoglobulin G. Infect Immun 1996; 64(12):5395-5398. PMID: 8945593.

32 Darenberg J, Ihendyane N, Sjolin J, et al. Intravenous immunoglobulin $\mathrm{G}$ therapy in streptococcal toxic shock syndrome: A European randomized, double-blind, placebo-controlled trial. Clin Infect Dis 2003; 37(3):333-340. PMID: 12884156.

${ }^{33}$ Kaul R, McGeer A, Norrby-Teglund, et al. Intravenous immunoglobulin therapy for streptococcal toxic shock syndrome - A comparative observational study. Clin Infect Dis 1999; 28(4):800-807. PMID: 10825042.

${ }^{34}$ Linnér A, Darenberg J, Sjolin J, Henriques-Normark B, Norrby-Teglund A. Clinical efficacy of polyspecific intravenous immunoglobulin therapy in patients with streptococcal toxic shock syndrome: A comparative observational study. Clin Infect Dis 2014; 59(6):851-857. PMID: 24928291.
KANSAS JOURNAL of MEDICINE GROUP G STREPTOCOCCUSAND NECROTIZING SOFT TISSUE INFECTION

continued.

35 Parks T, Wilson C, Curtis N, Norrby-Teglund A, Sriskandan S. Polyspecific intravenous immunoglobulin in clindamycin-treated patients with streptococcal toxic shock syndrome: A systematic review and meta-analysis. Clin Infect Dis 2018; 67(9):1434-1436. PMID: 29788397.

36 Gaunt N, Rogers K, Seal D, Denham M, Lewis J. Necrotising fasciitis due to group $\mathrm{C}$ and $\mathrm{G}$ haemolytic streptococcus after chiropody. Lancet 1984; 323(8375):516. PMID: 6142243.

Keywords: soft tissue infections, toxic shock syndrome, Streptococcus sp. 'group $G^{\prime}$ 